\title{
The Influence of Arabic Language Learning on Understanding of Islamic Legal Sciences-A Study in the Sultan Idris Education University
}

\author{
Nahla A. K. Alhirtani ${ }^{1}$ \\ ${ }^{1}$ Faculty of Languages, Sultan Idris Education University, Malaysia \\ Correspondence: Nahla A. K. Alhirtani, Faculty of Languages, Sultan Idris Education University, Malaysia. \\ E-mail: nahla@fbk.upsi.edu.my
}

Received: September 15, 2017

Accepted: October 19, 2017 Online Published: January 26, 2018

doi:10.5539/ies.v11n2p55

URL: https://doi.org/10.5539/ies.v11n2p55

\begin{abstract}
The most important in Islamic Legal Sciences is Arabic Language, because of its necessity for Muslims to understand the Islamic Legal Provisions in Qur'an and Hadith which are in Arabic and informed by Arabs, thus, to understand these sciences it is a must to learn Arabic to discern the meanings and benefits of Islamic Texts and Provisions. So based on induction and analysis, this study aims to illustrate the function of Arabic Language as a tool serves the Islamic Legal Sciences in the Sultan Idris Education University, by a questionnaire was disseminated among the students of Arabic Language to declare the efforts of Sultan Idris Education University in this field, especially within issues relate to understanding the Quran, its interpretation, and Islamic Legal Provisions.
\end{abstract}

Keywords: Arabic, Arabic Learning, Islamic provisions

\section{Introduction}

As defined by Al-Ghaliyeni (1993), the Arabic language is all the words Arabs use to name their items, and all the words which were transferred to us. It was protected by the Quran, Hadith, and the Arabs' prose and poetry. Such definition is based on what Ibn Jinni mentioned in his book The Characteristics (Al Khasa'es) that language "is sounds through which each people express themselves" (Ibn Jinni, 2010).

Allah-Subhanahu wa Ta'la- dictated the Holy Quran in clear and pure Arabic. Therefore, the relationship between Arabic and Sharia sciences is very strong, especially that the sources of such sciences are in Arabic.

The Arabic language plays an important role in the comprehension of the Islamic Sharia sciences since Arabic here is considered as an auxiliary science. In addition, the Malaysian Universities' use of Arabic as the language of teaching Sharia sciences contributes to the preparation of students who are excellent at Arabic so to deepen their understanding of such sciences. The universities do so through the implementation of several programs in Arabic such as debates, public speaking and others.

Furthermore, there are some Malaysian universities that teach Islamic Sharia sciences in Arabic. It has also been found that teaching Islamic Studies in Arabic results in students' mastery of Arabic language.

\section{Study Approach and Procedure}

\subsection{Study Problem and Questions}

This study seeks to answer a group of questions that represent the study problem, namely:

1) Does Arabic have a clear impact on the comprehension, learning, and deep understanding of the Holy Quran, its interpretation and the meanings of its words?

2) What role does Arabic play in the comprehension of the Hadiths and the understanding of their words?

3) Are there any differences and contradictions between students who learned Arabic and those who did not in understanding the Sharia rules?

4) What role does Sultan Idris Education University play in serving Sharia sciences through teaching their students Arabic language? 
5) What role does Sultan Idris Education University play as a model for serving Sharia sciences through teaching Arabic language?

\subsection{Study Objectives}

This study aims at:

1) Identifying the impact of learning Arabic language on understanding and learning the Holy Quran, its interpretation and the meanings of its words.

2) Analyzing the impact of learning Arabic on the understanding of Hadiths and their meanings.

3) Identifying the differences in the understanding of Sharia rules among students who learned Arabic and those who did not.

4) Identifying the role played by the Sultan Idris Education University as a model in serving Sharia sciences through teaching Arabic to their students.

\subsection{Study Significance}

This study seeks to show the efforts exerted by the different Sultan Idris Education University in the employment of Arabic in their attempt to serve Sharia sciences; considering the fact that Arabic is the language of the Holy Quran and is essential to the understanding of such sciences.

\subsection{Study Hypotheses}

- Teaching Arabic at Sultan Idris Education University plays an important role at $(\alpha \geq 0.05)$ in the comprehension of the interpretation of the Holy Quran.

- Teaching Arabic at Sultan Idris Education University plays an important role at $(\alpha \geq 0.05)$ in the comprehension of the Sharia rules.

- Teaching Arabic at Sultan Idris Education University plays an important role at $(\alpha \geq 0.05)$ in the comprehension of the Islamic Jurisprudence.

\subsection{Study Limitations}

The study was applied on the Sultan Idris Education University because they teach Islamic Studies in Arabic, and they offer Arabic Language Programs and Communicative Arabic Courses.

The study was conducted during the academic year 2016-2017; i.e. the study implementation continued in these two years.

\subsection{Study Structure}

Based on the approach followed by the researcher, the research structure consists of five basic chapters:

- Introduction.

- Study Approach and Procedure.

- Theoretical Background "Influence of the Arabic Language on Islamic Sciences".

- Practical Part.

- Conclusion: Findings and Recommendation.

- $\quad$ Sources and References.

\subsection{Data Collection Method}

In data collection, this study adopts the inductive approach. The study also uses the applied field approach (statistics) to reinforce the induction process. Data analysis, evaluation and statistics are all based on a questionnaire that is designed on educational basis.

\subsection{Study Tools}

Based on the data to be collected, the adopted approach, the time limit, and the available material capabilities; the researchers found that the best tool to achieve the study objectives is Questionnaire.

\subsection{Data Analysis Procedures}

This research relies on the analytical approach. It applies the Statistical Package for the Social Sciences for data analysis. 


\section{Theoretical Background-Influence of the Arabic Language on Islamic Sciences}

\subsection{Language Arabism and the Obligation of Its Learning}

The Arabic language is not exclusive to the Arabs like Banu Isra'el claimed that Torah was exclusive to the Jews. Islam is an international legislation, as Allah has said, "Blessed is He who sent down the Criterion upon His Servant that he may be to the worlds a warner" (Al-Furqan, 1) and said, "And We have not sent you except comprehensively to mankind as a bringer of good tidings and a warner. But most of the people do not know".

Ibn Taimiyyah (1999, p. 964) argues that Quran sciences cannot be studied without understanding the Arabic language: "the Arabic language is part of the religion, and knowledge about is an obligation. Understanding the Holy Book and the prophet's Sunnah is an obligation that cannot be understood without understanding the Arabic language, and what is necessary to fulfill an obligation is an obligation".

"If they unanimously agree on something, one can take it as proof without suspicion. If they disagree, it is not an argument against them or against the ones who come after them. This is due to the language of the Holy Quran, the Sunnah, or the Arabs in general". What he means about the language of the Holy Quran is that the word can have more than one meaning.

\subsection{Arabic language and Quran}

Without understanding the Arabic language, how can we grasp the Holy Quran? How can we embrace the correct Aqidah explained in Quran? How can we abide by the Quran's orders and prohibitions? How can we live by its standards?

Omar bin Al-Khattab once wrote to Abu Musa Al-Ash'ari-may Allah bless them both-, "Comprehend the Sunnah and study the Arabic language and the grammar of the Quran, which is Arabic".

Al-Bassri was asked, "What do you say of the people who learn the Arabic language?", he said, "Good for them; learning the language of their prophet".

Sheikh of Islam, Ibn Taimiyyah (1999, p. 964) said "Interpreting the Quran and the Sunnah aims at understanding the intention of Allah and his messenger from each utterance. How can that be achieved? Understanding the Arabic language, with which we have been addressed, and knowing the words' denotation help us understand the meaning of Allah's words. The misguidance of the people of bidah (innovation) is mainly for this reason; they attribute to the words of Allah and his apostle what they claim is true, but is not". He also said, "Because religion is made of sayings and actions, understanding Arabic is the way to understand the sayings and understanding the Sharia is the way to know the jurisprudence of actions" (Ibn Taimiyyah, 1999, p. 964).

Abu Hayyan commended Sibawayh, "Those who desire to learn exegesis and wish to enhance their writing and composition should thoroughly study the book of Sibawayh, as it is reliable in this art and is a good reference to resolve problems" (Al-Azhary, 1967, p. 482).

Al-Zarkashi said, "Do Know that those who are not experts in the Arabic language and its sciences have no right to interpret any of Allah's words, and it is not sufficient to know only a little, because the word may have two meanings and they may know one meaning while the intended is the other".

Therefore, Malik said, "If I encounter someone who is not expert in the language of the Arabs and dares to interpret Allah's Book, I shall seize him in exemplary punishment".

That is why we often find the interpretation books enriched with quotations from Sibawayh, Al-Akhfash, Al-Kisa'I, Al-Farra' and others. Knowing the meanings and secrets of Quran by heart requires recoursing to their sayings and resorting to their interpretations. Al-Zamakhshari in his book, Al-Mufassal, and Abu Obaid in "Fada'el Al-Quran" quoted Abu Bakr Al-Seddiq's saying "to determine the i'rab (syntax) of an ayah is favorable to me over memorizing an ayah", because understanding the syntax helps in understanding the meaning and the Quran was revealed for reflection and implementation.

\subsection{The Arabic Language and the Prophet's Sunnah}

The Sunnah is a clarification of the Quran, and the Sunnah is in Arabic, so we need the Arabic language to understand it. Knowing the Arabic language is a prerequisite for studying Hadith. Ibn Al-Salah said, "A learner of Hadith must have sufficient knowledge of the Arabic language and grammar that saves him the shame of solecism and distortion". Al-Khateeb quoted Shu'bah's saying "One who seeks to learn the Hadith without knowledge of the Arabic language is similar to one who wears a burnoose without having a head". He also quoted Hammad bin Salama's saying "One who seeks to learn Hadith without knowing grammar is like a donkey 
carrying a feedbag with no barley in it".

In the Introduction of his book Tahdhib al-Kamal fi asma' al-rijal, Al-Mizzi (1980, p. 591) said "He who wishes to study our book must achieve a good knowledge of the Arabic language grammar and syntax, the science of usul and furu' (Roots and Branches of Jurisprudence), science of Hadith as well as dates and people's history".

\subsection{The Arabic Language and the Aqidah}

Weakness in the linguistic sciences has caused the misguidance of many jurisprudence seekers. Ibn Jinni (2010, p. 245) said, "Most of those who lost their way amongst the Sharia people and deviated from the right approach did so because their weakness in this honorable language, through which all mankind is addressed, affected them and undermined their patience".

\subsection{The Arabic Language and Jurisprudence}

A true jurist should know the Arabic language very well. We already mentioned Omar's words to Abu Musa' "Comprehend the Sunnah and study the Arabic language and the grammar of the Quran for it is Arabic".

Omar's instruction contains two aspects: encouraging the study of the Arabic language and the study of Islamic Sharia (Al-Amedy, 2010, p. 426).

Ibn Taymiyyah explained Omar's advice: "because religion is made of sayings and actions, Understanding Arabic is the way to understand the sayings and understanding the Sunnah clarifies the jurisprudence of the actions".

Al-Shafi'i said, "When you speak of something, you know it by meaning without clarifying the term. You can also understand an indication, and that is the most sophisticated part of the language, because the experts understand it and the ignorant ones don't. One thing may have many names and one name can have many meanings".

"And there is no creature on earth but that upon Allah is its provision" (Hud, 6). This is general with no specification.

"So they set out, until when they came to the people of a town, they asked its people for food" (Al-Kahf, 77). This is general that indicates specification.

An example on one thing having different names in the noble Quran is the woman's dowry which was called "ajr, sadaq and mahr". In Ahkam Al-Quran, Al-Shafi'i gave an example on the words that have several meanings; the word "umma". In Az-Zukhruf - verse 23, the word umma was used to mean religion "We found our fathers upon a religion"; in Yusuf-verse 45, the same word means time "and remembered after a time"; and in An-Nahl-verse 120, it meant leader "Abraham was a [comprehensive] leader" (Al-Bayhaqi, 1994, p. 197).

\section{Practical Part}

\subsection{Methodology \& Procedures}

\subsubsection{Methodology}

The researcher used the analytic descriptive approach to fulfill the study purpose and adjectives. This approach studies the phenomenon as it exists on reality and describes it both quantitatively and qualitatively in an exact manner. Moreover, this approach does not only gather data related to the phenomenon under study and investigates its various relations, but also analyzes, links and interprets this data to reach conclusions. These conclusions are used as a foundation to the suggested perspective, which will enrich the information related to the subject of study (Abu Hatab \& Sadeq, 2005, p. 104).

\subsubsection{Population and Sample}

The population in this study is six different Sultan Idris Education University. The researchers used a random sample method where they distributed 55 questionnaires on the population. Only 49 questionnaires were retrieved with a response rate of $\% 89.1$. Below are the demographic characteristics of the population.

Demographic characteristics of the sample $(\mathrm{N}=49)$ 
Table 1. Distribution of sample according to age

\begin{tabular}{lcc}
\hline Age & Number & Percentage \% \\
\hline $25-20$ & 145 & 100.0 \\
$30-26$ & - & - \\
$35-31$ & - & - \\
$40-36$ & - & - \\
$50-46$ & - & - \\
\hline
\end{tabular}

Table 2. Distribution of sample according to gender

\begin{tabular}{lcc}
\hline Gender & Number & Percentage $\%$ \\
\hline male & 47 & 32.4 \\
female & 98 & 67.6 \\
\hline
\end{tabular}

Table 3. Distribution of sample according to nationality

\begin{tabular}{ccc}
\hline Nationality & Number & Percentage $\%$ \\
\hline Malaysian & 144 & 99.3 \\
other & 1 & 0.7 \\
\hline
\end{tabular}

Table 4. Distribution of sample according to the mother tongue

\begin{tabular}{lcc}
\hline Mother tongue & Number & Percentage\% \\
\hline Malaysian & 144 & 99.3 \\
Chinese & 1 & 0.7 \\
Indian & - & - \\
\hline
\end{tabular}

Table 5. Distribution of sample according to the academic program

\begin{tabular}{ccc}
\hline Academic program & Number & Percentage $\%$ \\
\hline doctorate & - & - \\
master & 2 & 1.4 \\
bachelor & 143 & 98.6 \\
college & - & - \\
\hline
\end{tabular}

Table 6. Distribution of sample according to specialization

\begin{tabular}{lcc}
\hline Specialization & Number & Percentage $\%$ \\
\hline Arabic Language & 108 & 74.5 \\
Islamic Studies & 35 & 24.1 \\
other & 2 & 1.4 \\
\hline
\end{tabular}

- Table 1 shows that the all of sample are between 20 and 25. This is a reasonable outcome since most of the samples are from the bachelor degree.

- Table 2 shows that the majority of the samples are females with a percentage of $67.6 \%$ while only $32.4 \%$ of the samples are males.

- Both Tables $3 \& 4$ shows that the majority of the sample are Malaysian whose first language is Malaysian with percentage of $99.3 \%$ respectively. This is predictable since the population of this study is Malaysian universities.

- Table 5 shows that the majority of the sample are students of bachelor degree with a percentage of $98.6 \%$

- Table 6 shows that percentages of $74.5 \%$ of the sample are specialized in Arabic Language, percentage of $24.1 \%$ are specialized in Islamic Studies. 


\subsubsection{Research Tool}

A questionnaire is designed to investigate "The Role of Sultan Idris Education University in Teaching Arabic Language to Promote Students' knowledge in Islamic Studies". Fifth Likert scale is used to measure the responses of the test subjects to the questionnaire items.

Table 7. Fifth Likert scale

\begin{tabular}{cccccc}
\hline Response & Strongly Agree & Agree & Neutral & Disagree & Strongly disagree \\
\hline rate & 5 & 4 & 3 & 2 & 1 \\
\hline
\end{tabular}

\subsubsection{Research Tool Validity}

Questionnaire validity means, "The questionnaire measures what it was designed to measure" (Gergawi, 2010, p. 105). The researchers confirmed the validity of the questionnaire by adopting measurement validity, which is divided into:

Internal consistency: means how each item of the questionnaire items is consistence with the domain of the item. The researchers used the correlation coefficient to measure the internal consistency.

Table 8 shows the correlation coefficient between the items of "The effect of Arabic Language in understanding the interpretation of Qur'an" and the overall degree of the domain with level of significance $\alpha \leq 0.05$. This means that the correlation coefficient is significant at level of significance 0.05 and the domain is valid.

Table 8. The correlation coefficient between the items of "The effect of Arabic Language in understanding the interpretation of Qur' an" and the overall degree of the domain

\begin{tabular}{|c|c|c|c|}
\hline & Item & $\begin{array}{l}\text { Correlation } \\
\text { coefficient }\end{array}$ & $\mathrm{p}$ value \\
\hline 1 & I can read different books of interpretations of the Qur'an because I have learned Arabic. & .633 & $<0.001$ \\
\hline 2 & I can know different reading styles of the Qur'an because I have learned Arabic. & .799 & $<0.001$ \\
\hline 3 & I can understand the impact of different reading styles of the Qur'an on its interpretations. & .692 & $<0.001$ \\
\hline 4 & $\begin{array}{l}\text { I am able to understand the effect of morphological construction in determining the meaning of the } \\
\text { words of the Qur'an. }\end{array}$ & .807 & $<0.001$ \\
\hline 5 & Due to learning of Arabic, I know the impact of Arabic grammar in the interpretation of the Qur'an. & .715 & $<0.001$ \\
\hline 6 & I know the impact of Synonymy on interpretation of the Qur'an. & .727 & $<0.001$ \\
\hline 7 & $\begin{array}{l}\text { I understand the implications /indications/meanings of the action sentence (verbs/actual) on } \\
\text { interpretation of the Qur'an. }\end{array}$ & .744 & $<0.001$ \\
\hline 8 & $\begin{array}{l}\text { I understand the implications /indications /meanings of the nominal sentence on interpretation of the } \\
\text { Qur'an. }\end{array}$ & .736 & $<0.001$ \\
\hline 9 & I know the effect of metaphor in understanding the Qur'an. & .758 & $<0.001$ \\
\hline 10 & I know the effect of the sentence structures on interpretation of the Qur'an. & .764 & $<0.001$ \\
\hline 11 & I know the effect of the semantics on interpretation of the Qur'an. & .791 & $<0.001$ \\
\hline 12 & I know the effect of the rhetorical method on interpretation of the Qur'an. & .780 & $<0.001$ \\
\hline
\end{tabular}

Table 9 illustrates the correlation coefficient between the items of "The effect of Arabic Language in understanding the Islamic Law/Shariah Provisions" and the overall degree of the domain with level of significance $\alpha \leq 0.05$, which means that the correlation coefficient is significant and the domain is valid. 
Table 9. Correlation coefficient between the items of "The effect of Arabic Language on understanding the Islamic Law/Shariah Provisions" and the overall degree of the domain

\begin{tabular}{llll}
\hline & Item & Correlation coefficient & p value \\
\hline 1 & $\begin{array}{l}\text { My knowledge of has helped me to understand the Islamic } \\
\text { Law/Shariah provisions }\end{array}$ & .643 & $<0.001$ \\
2 & $\begin{array}{l}\text { My knowledge of Arabic has helped me to comprehend the Islamic } \\
\text { Legal issues/law matters }\end{array}$ & .732 & $<0.001$ \\
3 & $\begin{array}{l}\text { I can link between the Islamic Legal rulings and the lives of Muslims } \\
\text { The student of Islamic Studies who does not know Arabic will have } \\
4\end{array} \quad \begin{array}{l}\text { difficulties to understand the legitimate Arabic texts } \\
\text { The student of Islamic Studies who does not know Arabic Grammar } \\
\text { will have difficulties to obtain better understanding of the Qur'an }\end{array}$ & .721 & $<0.001$ \\
& $\begin{array}{l}\text { My knowledge of context helped me to obtain better understanding } \\
\text { of Islamic Law }\end{array}$ & .721 & $<0.001$ \\
7 & $\begin{array}{l}\text { less of Arabic Synonymies lead to the lack of understanding in the } \\
\text { Islamic Law }\end{array}$ & .779 & $<0.001$ \\
\end{tabular}

Table 10 shows the correlation coefficient between the items of "The effect of Arabic language in understanding Islamic Jurisprudence" and the overall degree of the domain. The data in this table shows that the correlation coefficient is significant with level of significance $\alpha \leq 0.05$. This level of significance shows that the domain is valid.

Table 10. The correlation coefficient between the items of "The effect of Arabic language in understanding Islamic Jurisprudence" and the overall degree of the domain

\begin{tabular}{llcc}
\hline & Item & Correlation coefficient & $\mathrm{p}$ value \\
\hline 1 & $\begin{array}{l}\text { My knowledge of Arabic helped me to understand the Islamic } \\
\text { Jurisprudence }\end{array}$ & .676 & $<0.001$ \\
2 & I understand different Islamic Jurisprudence issues & .764 & $<0.001$ \\
3 & I can make a link between the different jurisprudential provisions & .793 & $<0.001$ \\
4 & $\begin{array}{l}\text { I can understand the Islamic Jurisprudence that regulate the } \\
\text { relationship between individuals and the societies }\end{array}$ & .793 & $<0.001$ \\
5 & $\begin{array}{l}\text { There is a strong relationship between Arabic and Islamic } \\
\text { Jurisprudence }\end{array}$ & .680 & $<0.001$ \\
6 & $\begin{array}{l}\text { I can read Islamic Jurisprudence books with deep comprehension } \\
7\end{array}$ & $\begin{array}{l}\text { I use Arabic dictionary to understand some words in Islamic } \\
\text { Jurisprudence }\end{array}$
\end{tabular}

*Correlation coefficient is statistically significant at $\alpha \leq 0.05$.

Construct validity: is one of the measurements of tool validity; it measures how well did the tool achieved its objectives. It also shows the correlation coefficient between the items of the questionnaire.

Table 11 shows that all correlation coefficients between the items of the questionnaire are statistically significant at level of significance $\alpha \leq 0.05$. Therefore, all of the domains of the questionnaire are valid.

Table 11. The correlation coefficient between all the items of the questionnaire

\begin{tabular}{lcc}
\hline Item & Correlation coefficient & $\mathrm{p}$ value \\
\hline The effect of Arabic Language in understanding the interpretation of Qur'an & .928 & $<0.001$ \\
The effect of Arabic Language in understanding the Islamic Law / Shariah Provisions & .822 & $<0.001$ \\
The effect of Arabic language in understanding Islamic Jurisprudence & .880 & $<0.001$ \\
\hline
\end{tabular}

\subsubsection{Questionnaire Reliability}

"It means that the questionnaire gives the same results if it was applied many times." (Gergawi, 2010, p. 97). 
Cronbach's Alpha is the most popular tests used to measure reliability.

Table 12 shows that Cronbach's Alpha value for each item is high, since it was (0.971) for all of the items. This means that the reliability factor is high and statistically accepted.

Table 12. Cronbach's Alpha for questionnaire reliability

\begin{tabular}{llcc}
\hline & Item & Items number & Cronbach's Alpha \\
\hline 1 & The effect of Arabic Language in understanding the interpretation of Qur'an & 12 & 0.927 \\
2 & The effect of Arabic Language in understanding the Islamic Law / Shariah Provisions & 7 & 0.838 \\
3 & The effect of Arabic language in understanding Islamic Jurisprudence & 7 & 0.849 \\
& All questionnaire items & 26 & 0.945 \\
\hline
\end{tabular}

The results of both validity and reliability tests show that the measurement tool (questionnaire) is valid and reliable. This makes it an effective and suitable tool for this study.

\subsubsection{Statistical Tools Used in This Study}

Statistical Package for the Social Sciences (SPSS) program was used to analyze the data collected using the questionnaire. The following statistical tests were applied:

1) Frequencies and Percentages for describing the sample.

2) The mean, relative weight and standard deviation.

3) Cronbach's Alpha for questionnaire reliability.

4) Person correlation coefficient for correlation degree.

5) Independent Sample T-Test to know if there are statistically significant differences between two independent sets of data.

6) One Way Analysis of Variance (ANOVA) to know if there are any statistically significance differences between three or more sets of data.

\subsection{Data Analysis and Hypothesis Testing}

4.2.1 The Effect of Teaching Arabic Language in the Sultan Idris Education University in Understanding Qur'an Interpretation

The following hypothesis will be tested:

Teaching Arabic language at the Sultan Idris Education University has a significant rule at level of significance $\alpha$ $\leq 0.05$ on understanding Qur'an interpretation.

The researchers used the mean, standard deviation, relative weight, and T-test to test this hypothesis. These tests were used to investigate whether the average response rate reached the neutral point, which equals three. Table 13 shows those results.

Table 13. Mean, standard deviation, relative weight, and T-test for the effect of Arabic language in understanding the interpretation of Qur'an

\begin{tabular}{|c|c|c|c|c|c|c|c|}
\hline & Item & Mean & $\begin{array}{c}\text { Std. } \\
\text { deviation }\end{array}$ & $\begin{array}{l}\text { Relative } \\
\text { weight }\end{array}$ & $\begin{array}{l}\text { T-test } \\
\text { value }\end{array}$ & Sig. & rank \\
\hline 1 & $\begin{array}{l}\text { I can read different books of interpretations of } \\
\text { the Qur'an because I have learned Arabic }\end{array}$ & 4.19 & 0.739 & 83.86 & 19.45 & $<0.001$ & 5 \\
\hline 2 & $\begin{array}{l}\text { I can know different reading styles of the } \\
\text { Qur'an because I have learned Arabic }\end{array}$ & 4.30 & 0.739 & 86.07 & 21.24 & $<0.001$ & 1 \\
\hline 3 & $\begin{array}{l}\text { I can understand the impact of different reading } \\
\text { styles of the Qur'an on its interpretations }\end{array}$ & 4.15 & 0.748 & 83.03 & 18.53 & $<0.001$ & 9 \\
\hline 4 & $\begin{array}{l}\text { I am able to understand the effect of } \\
\text { morphological construction in determining the } \\
\text { meaning of the words of the Qur'an }\end{array}$ & 4.17 & 0.799 & 83.31 & 17.56 & $<0.001$ & 8 \\
\hline
\end{tabular}




\begin{tabular}{|c|c|c|c|c|c|c|c|}
\hline & Due to learning of Arabic I know the impact of & & & & & & \\
\hline 5 & $\begin{array}{l}\text { Arabic grammar in the interpretation of the } \\
\text { Qur'an }\end{array}$ & 4.27 & 0.748 & 85.38 & 20.44 & $<0.001$ & 2 \\
\hline 6 & $\begin{array}{l}\text { I know the impact of Synonymy on } \\
\text { interpretation of the Qur'an }\end{array}$ & 4.19 & 0.710 & 83.86 & 20.23 & $<0.001$ & 5 \\
\hline 7 & $\begin{array}{l}\text { I understand the implications } \\
\text { /indications/meanings of the action sentence } \\
\text { (verbs/actual) on interpretation of the Qur'an }\end{array}$ & 4.24 & 0.700 & 84.83 & 21.36 & $<0.001$ & 3 \\
\hline & I understand the implications & & & & & & \\
\hline 8 & $\begin{array}{l}\text { /indications/meanings of the nominal sentence } \\
\text { on interpretation of the Qur'an }\end{array}$ & 4.21 & 0.747 & 84.28 & 19.56 & $<0.001$ & 4 \\
\hline 9 & $\begin{array}{l}\text { I know the effect of metaphor in understanding } \\
\text { the Qur'an }\end{array}$ & 4.08 & 0.821 & 81.66 & 15.89 & $<0.001$ & 12 \\
\hline 10 & $\begin{array}{l}\text { I know the effect of the sentence structures on } \\
\text { interpretation of the Qur'an }\end{array}$ & 4.19 & 0.782 & 83.72 & 18.27 & $<0.001$ & 7 \\
\hline 11 & $\begin{array}{l}\text { I know the effect of the semantics on } \\
\text { interpretation of the Qur'an }\end{array}$ & 4.12 & 0.857 & 82.48 & 15.79 & $<0.001$ & 10 \\
\hline \multirow[t]{2}{*}{12} & $\begin{array}{l}\text { I know the effect of the rhetorical method on } \\
\text { interpretation of the Qur'an }\end{array}$ & 4.08 & 0.812 & 81.66 & 16.05 & 0.006 & 11 \\
\hline & $\begin{array}{l}\text { The effect of Arabic language in understanding } \\
\text { the interpretation of Qur'an in general. }\end{array}$ & 4.18 & 0.573 & 83.68 & 24.88 & $<0.001$ & \\
\hline
\end{tabular}

Table 13 shows that the mean for all of the items is 4.18 and the relative weight is $83.68 \%$. It also shows that the T-test value is 24.88 and Sig. is less than the level of significance, which indicates that all sample members agree on all the items related to the effect of Arabic language in understanding Qur'an interpretation.

The item "I can know different reading styles of the Qur'an because I have learned Arabic", scored the highest approval percentage $86.07 \%$. Whereas, the item "I know the effect of metaphor in understanding the Qur'an", scored the lowest approval percentage $81.66 \%$.

4.2.2 The Effect of Arabic Language Teaching in The Sultan Idris Education University on understanding the Islamic Law/Shariah Provisions

The following hypothesis will be tested:

Teaching Arabic language at the Sultan Idris Education University has a significant rule at level of significance $\alpha$ $\leq 0.05$ on understanding Islamic Law.

The researchers used the mean, standard deviation, relative weight, and T-test to test this hypothesis. These tests were used to investigate whether the average response rate reached the neutral point, which equals three. Table 14 shows those results.

Table 14. Mean, standard deviation, relative weight, and T-test for the effect of Arabic language in understanding the Islamic Law

\begin{tabular}{|c|c|c|c|c|c|c|c|}
\hline & Item & Mean & $\begin{array}{c}\text { Std. } \\
\text { deviation }\end{array}$ & $\begin{array}{c}\text { Relative } \\
\text { weight }\end{array}$ & $\begin{array}{l}\text { T-test } \\
\text { value }\end{array}$ & Sig. & rank \\
\hline 1 & $\begin{array}{l}\text { My knowledge of has helped me to understand the Islamic } \\
\text { Law/Shariah provisions. }\end{array}$ & 4.48 & 0.625 & 89.66 & 28.58 & $<0.001$ & 1 \\
\hline 2 & $\begin{array}{l}\text { My knowledge of Arabic has helped me to comprehend the Islamic } \\
\text { Legal issues/law matters. }\end{array}$ & 4.41 & 0.662 & 88.28 & 25.70 & $<0.001$ & 3 \\
\hline 3 & $\begin{array}{l}\text { I can link between the Islamic Legal rulings and the lives of } \\
\text { Muslims }\end{array}$ & 4.37 & 0.707 & 87.45 & 23.39 & $<0.001$ & 4 \\
\hline 4 & $\begin{array}{l}\text { The student of Islamic Studies who does not know Arabic will have } \\
\text { difficulties to understand the legitimate Arabic texts. }\end{array}$ & 4.33 & 0.727 & 86.62 & 22.05 & $<0.001$ & 7 \\
\hline
\end{tabular}




\begin{tabular}{|c|c|c|c|c|c|c|c|}
\hline 5 & $\begin{array}{l}\text { The student of Islamic Studies who does not know Arabic } \\
\text { Grammar will have difficulties to obtain better understanding of the } \\
\text { Qur'an }\end{array}$ & 4.42 & 0.723 & 88.41 & 23.65 & $<0.001$ & 2 \\
\hline 6 & $\begin{array}{l}\text { My knowledge of context helped me to obtain better understanding } \\
\text { of Islamic Law }\end{array}$ & 4.35 & 0.651 & 87.03 & 25.00 & $<0.001$ & 5 \\
\hline 7 & $\begin{array}{l}\text { Less of Arabic Synonymies lead to lack understanding in the } \\
\text { Islamic Law }\end{array}$ & 4.33 & 0.717 & 86.62 & 22.34 & $<0.001$ & 6 \\
\hline & The effect of Arabic language in understanding the Islamic Law & 4.39 & 0.491 & 87.72 & 34.02 & $<0.001$ & \\
\hline
\end{tabular}

Table 14 shows that the mean for all of the items is 4.39 and the relative weight is $87.72 \%$. It also shows that the T-test value is 34.02 and Sig. is less than the level of significance, which indicates that all sample members agree on all the items related to the effect of Arabic language in understanding Islamic law.

The item "My knowledge of has helped me to understand the Islamic Law/Shariah provisions", scored the highest approval percentage $89.66 \%$. Whereas, the item" The student of Islamic Studies who does not know Arabic will have difficulties to understand the legitimate Arabic texts", scored the lowest approval percentage $86.62 \%$.

4.2.3 The Effect of Arabic Language Teaching in the Sultan Idris Education University on Understanding the Islamic Jurisprudence

The following hypothesis will be tested:

Teaching Arabic language at the Sultan Idris Education University has a significant rule at level of significance $\alpha$ $\leq 0.05$ on understanding Islamic Jurisprudence.

The researchers used the mean, standard deviation, relative weight, and T-test to test this hypothesis. These tests were used to investigate whether the average response rate reached the neutral point, which equals three. Table 15 shows those results.

Table 15. Mean, standard deviation, relative weight, and T-test for the effect of Arabic language in understanding the Islamic Jurisprudence

\begin{tabular}{|c|c|c|c|c|c|c|c|}
\hline & Item & Mean & $\begin{array}{c}\text { Std. } \\
\text { deviation }\end{array}$ & $\begin{array}{c}\text { Relative } \\
\text { weight }\end{array}$ & $\begin{array}{l}\text { T-test } \\
\text { value }\end{array}$ & sig. & rank \\
\hline 1. & $\begin{array}{l}\text { My knowledge of Arabic helped me to understand the Islamic } \\
\text { Jurisprudence }\end{array}$ & 4.45 & 0.655 & 88.97 & 26.61 & $<0.001$ & 1 \\
\hline 2. & I understand different Islamic Jurisprudence issues & 4.22 & 0.759 & 84.41 & 19.37 & $<0.001$ & 5 \\
\hline 3. & $\begin{array}{l}\text { I can make a link between the different jurisprudential } \\
\text { provisions }\end{array}$ & 4.18 & 0.822 & 83.59 & 17.27 & $<0.001$ & 7 \\
\hline 4. & $\begin{array}{l}\text { I can understand the Islamic Jurisprudence that regulate the } \\
\text { relationship between individuals and the societies }\end{array}$ & 4.24 & 0.793 & 84.83 & 18.85 & $<0.001$ & 4 \\
\hline 5. & $\begin{array}{l}\text { There is a strong relationship between Arabic and Islamic } \\
\text { Jurisprudence } \\
\text { to obtain better understanding of the Qur'an }\end{array}$ & 4.37 & 0.695 & 87.31 & 23.65 & $<0.001$ & 2 \\
\hline 6. & $\begin{array}{l}\text { I can read Islamic Jurisprudence books with deep } \\
\text { comprehension }\end{array}$ & 4.20 & 0.813 & 84.00 & 17.77 & $<0.001$ & 6 \\
\hline 7. & $\begin{array}{l}\text { I use Arabic dictionary to understand some words in Islamic } \\
\text { Jurisprudence }\end{array}$ & 4.31 & 0.692 & 86.21 & 22.79 & $<0.001$ & 3 \\
\hline 8. & $\begin{array}{l}\text { The effect of Arabic language in understanding the Islamic } \\
\text { Jurisprudence }\end{array}$ & 4.28 & 0.543 & 85.62 & 28.41 & $<0.001$ & \\
\hline
\end{tabular}

Table 15 shows that the mean for all of the items is 4.28 and the relative weight is $85.62 \%$. It also shows that the T-test value is 28.41 and Sig. is less than the level of significance, which indicates that all sample members agree on all the items related to the effect of Arabic language in understanding Islamic law.

The item "My knowledge of Arabic helped me to understand the Islamic Jurisprudence", scored the highest approval percentage $88.97 \%$. Whereas, the item "I can make a link between the different jurisprudential 
provisions", scored the lowest approval percentage $83.59 \%$.

\section{Conclusion}

\subsection{Findings of Distributing the Sample Individuals by Demographic Data}

Table 1 shows that the all of sample are between 20 and 25. This is a reasonable outcome since most of the samples are from the bachelor degree.

Table 2 shows that the majority of the samples are females with a percentage of $67.6 \%$ while only $32.4 \%$ of the samples are males.

Both Tables $3 \& 4$ shows that the majority of the sample are Malaysian whose first language is Malaysian with percentage of $99.3 \%$ respectively. This is predictable since the population of this study is Malaysian universities.

Table 5 shows that the majority of the samples are students of bachelor degree with a percentage of $98.6 \%$

Table 6 shows that percentages of $74.5 \%$ of the sample are specialized in Arabic Language, percentage of $24.1 \%$ are specialized in Islamic Studies.

\subsection{Data Analysis and Study Hypotheses Testing}

Table 14 shows that the mean for all of the items is 4.18 and the relative weight is $83.68 \%$. It also shows that the T-test value is 24.88 and Sig. is less than the level of significance, which indicates that all sample members agree on all the items related to the effect of Arabic language in understanding Qur'an interpretation.

The item "I can know different reading styles of the Qur'an because I have learned Arabic", scored the highest approval percentage $86.07 \%$. Whereas, the item "I know the effect of metaphor in understanding the Qur'an", scored the lowest approval percentage $81.66 \%$.

Table 15 shows that the mean for all of the items is 4.39 and the relative weight is $87.72 \%$. It also shows that the T-test value is 34.02 and Sig. is less than the level of significance, which indicates that all sample members agree on all the items related to the effect of Arabic language in understanding Islamic law.

The item "My knowledge of has helped me to understand the Islamic Law/Shariah provisions", scored the highest approval percentage $89.66 \%$. Whereas, the item" The student of Islamic Studies who does not know Arabic will have difficulties to understand the legitimate Arabic texts", scored the lowest approval percentage $86.62 \%$.

Table 16 shows that the mean for all of the items is 4.28 and the relative weight is $85.62 \%$. It also shows that the T-test value is 28.41 and Sig. is less than the level of significance, which indicates that all sample members agree on all the items related to the effect of Arabic language in understanding Islamic law.

The item "My knowledge of Arabic helped me to understand the Islamic Jurisprudence", scored the highest approval percentage $88.97 \%$. Whereas, the item "I can make a link between the different jurisprudential provisions", scored the lowest approval percentage $83.59 \%$.

\subsection{Recommendations}

The researchers recommend the university under study to:

- Improve the level of teaching the Arabic language in the university.

- $\quad$ Reinforce the linkage between the Arabic language and the Islamic sciences.

- $\quad$ Propose more courses where the Arabic language is integrated with the Islamic sciences.

- $\quad$ Encourage using the Arabic language to teach Islamic sciences.

- Reinforce the lecturer's role in using the Arabic language in the lecture.

- Approve the Arabic language for writing the researches related to the Arabic language or Islamic sciences.

- Enrich the Arabic language students' Islamic sense to help them understand how the Arabic language serves Islamic sciences.

\section{References}

Abu Hatab, F., \& Sadeq, A. (2005). Research Approaches and Statistical Analysis Methods in Psychological, Educational and Social Sciences. Egyptian Anglo Library: Cairo.

Abu Musa, A. (1989). Al-Balagha Al-Qur'aniyah fi Tafsir Al-Zamakhshari. Dar Al-Fekr Al-Arabi: Cairo.

Al-Amedy. (2010). Elehkam Fe Osol Alahkam. Almktab Aleslamy, Beirut. 
Al-Azhary. (1967). Tahtheeb Alloghaa (2nd ed.). Dar eltorath: Beirut.

Al-Bayhaqi. (1994). AHKAAM ALQORAAN. Almktab Aleslamy, Beirut.

Al-Ghaliyeni, M. (1993). Jami'Al-Duroos Al-Arabiya (28th ed.). Publisher: Saida, Beirut.

Al-Ghazali. (1993). Al-Mustasfa (1st ed.). Dar al-Kotob ala-Ilmiyh.

Al-Hafez, Y. A. (1980). Tahtheeb Alkamal Fe Asmaa Alregal (2nd ed.). Beirut.

Al-Jerjawi, Z. (2010). Systematic Rules for Questionnaire Construction (2nd ed.). Al-Jarrah Sons, Palestine.

Al-Mizzi, A. Y. (1980). Tahtheeb Alkamal Fe Asmaa Alregal (2nd ed.). Beirut.

Al-Qurtubi. (1964) Tafsir Al-Qurtubi, second edition, Egyptian National Library: Cairo.

Al-Shafi'i. (1940). Al-Resalah (1st ed.). Egypt.

Al-Shatibi. (1992). Al-I'tisam (1st ed.). Ebn Affan Publising House: KSA.

Al-Shatibi. (1997). Al-Muwafaqaat (1st ed.). Ebn Affan Publishing House.

Al-Suyuti. (1426 AH). Itqan fi Ulum Al-Quran. King Fahd Complex for the Printing of the Holy Qur'an.

Al-Tabari. (2001). Tafsir Al-Tabari (1st ed.). Hajr Printing, Publishing, Ditribution, and Advertisement.

Ibn Hajar, A. A. (1997). Al-'Isaba fe tamyeez Al-Sahaba (1st ed.)

Ibn Jinni. (2010). Al-khasa'es (4th ed.). General Egyptian Book Organization.

Ibn Kathir. (1419AH). Tafsir ibn Kathir (1st ed.). Dar al-Kotob al-Ilmiyh: Beirut.

Ibn Khaldoun. (2004). Muqaddima. Yu'rub Publishing House.

Ibn Taimiyyah. (1369AH). Iqteda' Al-Serat Al-Mustaqeem fe Mukhalafet As'hab Al-Jahim (2nd ed.). Al-Sunna Al-Muhammadeyya Library: Cairo.

Ibn Taimiyyah. (1995). Fatawa Ibn Taimiyyah. King Fahd Complex for the Printing of the Holy Qur'an: Medina, Kingdom of Saudi Arabia.

The Noble Quran.

\section{Copyrights}

Copyright for this article is retained by the author(s), with first publication rights granted to the journal.

This is an open-access article distributed under the terms and conditions of the Creative Commons Attribution license (http://creativecommons.org/licenses/by/4.0/). 